\section{Allogeneic hematopoietic stem cell transplantation for primary central nervous system lymphoma}

Over the last decade, treatment of primary central nervous system lymphoma (PCNSL) has improved as a result of pivotal clinical trials. Myeloablative chemotherapy and autologous hematopoietic stem cell transplantation (autoHSCT) are now considered important components in first-line and later therapy. ${ }^{1}$ Salvage treatment after autoHSCT remains challenging, and allogeneic hematopoietic stem cell transplantation (alloHSCT) thus far has only been reported in case reports. However, different lines of evidence point to the therapeutic potential of immunological mechanisms against PCNSL. Indeed, immunomodulatory drugs showed clinical activity in PCNSL, with overall response rates (ORR) of $50-67 \%$ in salvage situations. ${ }^{1,2}$ In a small study, immune checkpoint inhibition by nivolumab was effective with durable responses in five PCNSL patients. ${ }^{3}$ Additionally, Varadi et al. observed continuous PCNSL shrinkage in parallel to overt graft-versus-host disease (GvHD) following nonmyeloablative conditioning with cyclophosphamide and alloHSCT. ${ }^{4}$ It is assumed that the phenomenon of gradual disappearance of chemoresistant lymphoma is in keeping with graft-versus-lymphoma immunoreaction (GvL) mediated by $\mathrm{T}$ cells and monocytes trafficking the central nervous system (CNS). Hence, GvL after alloHSCT may be effective against PCNSL.

We conducted a retrospective cohort study of patients with PCNSL who received alloHSCT in two German departments (Bochum and Franfurt, Oder). We identified six PCNSL patients treated with alloHSCT between 2013 and 2017, five of whom were early relapses. Two of six patients died after alloHSCT: one patient due to extensive $\mathrm{GvHD}$ and one due to lymphoma relapse. With a minimum follow up of 45 months, four patients are still alive and free of lymphoma. In summary, this is the first report of clinical characteristics including long-term follow up in a cohort of PCNSL patients successfully treated by alloHSCT.

Patients with PCNSL, histopathologically confirmed as diffuse large B-cell lymphoma, and prior autoHSCT who had undergone alloHSCT were included in this study. Median age at time of alloHSCT was 56 years; male and female patients were equally distributed. All patients had an adequate performance status at time of alloHSCT (Karnofsky-Index at least $80 \%$ ). AlloHSCT were performed in different lines of PCNSL therapy; the mean number of previous therapies was 2.3. No whole brain radiotherapy (WBRT) had been performed in any case either prior to nor after alloHSCT.

Considering therapies before alloHSCT, all patients had received high-dose methotrexate (HD-MTX) in combination with high-dose cytarabine or ifosfamide. In Patients 1 and 5, MTX, cytarabine, and prednisolone had been administered intrathecally or intraventricularly in parallel to systemic chemotherapy. All patients had received rituximab in first-line therapy and again in second- and third-line therapy, regardless of response in first-line (Table 1). Mean progression-free survival (PFS) after first-line therapy was 8.3 months, and 4 of 6 patients relapsed within 12 months, indicating highly aggressive disease.

Three patients $(50 \%$; Patients 2, 3, 4; Table 1) were treated with consolidative high-dose chemotherapy and autoHSCT in first-line. In Patients 1, 5, and 6, myeloablative chemotherapy and autoHSCT were administered after first relapse in second-line. All high-dose regimens comprised carmustine (BCNU), thiotepa, and rituximab as previously described. ${ }^{5,6}$

PCNSL Patients 1, 2, and 3 relapsed after autoHSCT (Table 1). Salvage therapies in these situations were chosen individually with the aim of bridging to alloHSCT. In

Table 1. Primary central nervous system lymphoma (PCNSL) treatments and clinical course prior to allogeneic hematopoietic stem cell transplantation (alloHSCT).

\begin{tabular}{|c|c|c|c|c|c|}
\hline Patient $n$. & First-Ine therapy & $\begin{array}{c}\text { PFS } \\
\left(1^{\text {stline }}\right)\end{array}$ & Second-line therapy & $\begin{array}{c}\text { PFS } \\
\left(2^{\text {nd }} \text { line) }\right.\end{array}$ & Third-line therapy \\
\hline 1 & $\begin{array}{l}\text { R/HD-MTX/Ifo and } \\
\text { AraC/MTX/Pred Omaya ( } 3 \text { course) } \\
\text { HD-AraC / Ifo (alternating) } \\
\text { and HD-MTX ( } 4 \text { courses) }\end{array}$ & 8 months & $\begin{array}{c}\text { R/AraC/TT (1 course) } \\
\text { R/BCNU/TT + autoHSCT }\end{array}$ & 9 Mo. & $\begin{array}{l}\text { R/HD-MTX } \\
(6 \text { courses })\end{array}$ \\
\hline 2 & $\begin{array}{l}\text { R/HD-AraC and R/HD-MTX } \\
\text { (4 courses, alternating) } \\
\text { R/BCNU/TT + autoHSCT }\end{array}$ & 12 months & R/HD-MTX ( 6 courses) & $\begin{array}{l}\text { bridge to } \\
\text { alloHSCT }\end{array}$ & \\
\hline 3 & $\begin{array}{l}\text { R/HD-MTX/Ifo (2 courses) } \\
\text { R/HD-AraC/TT (1 course) } \\
\text { R/BCNU/TT + autoHSCT }\end{array}$ & 7 months & $\begin{array}{l}\text { R/HD-MTX/AraC } \\
\text { (3 courses) }\end{array}$ & $\begin{array}{c}\text { bridge } \\
\text { to alloHSCT }\end{array}$ & \\
\hline 4 & $\begin{array}{l}\text { R/HD-MTX/Ifo (3 courses) } \\
\text { BCNU/TT/Eto + autoHSCT }\end{array}$ & 9 months & $\begin{array}{l}\text { R/HD-AraC/TT } \\
\text { ( } 2 \text { courses) }\end{array}$ & $\begin{array}{l}\text { bridge to } \\
\text { alloHSCT }\end{array}$ & \\
\hline 5 & $\begin{array}{l}\text { R/HD-MTX/Ifo and AraC i.t. } \\
(3 \text { courses })\end{array}$ & & R/BCNU/TT + autoHSCT & & \\
\hline 6 & R/HD-MTX/Ifo (3 courses) & 14 months & $\begin{array}{c}\text { R/HD-AraC/TT (2 courses) } \\
\text { R/BCNU/TT + autoHSCT }\end{array}$ & $\begin{array}{l}\text { bridge to } \\
\text { alloHSCT }\end{array}$ & \\
\hline
\end{tabular}

PFS: progression-free survival; autoHSCT: autologous hematopoietic stem cell transplantation; R: rituximab; HD-MTX: high-dose methotrexate; Ifo: ifosfamide; AraC: cytarabine; Pred: prednisolon; Omaya: Omaya Reservoir; TT: thiotepa, Eto: etoposide; BCNU: carmustin. 
Patients 4 to 6 , alloHSCT was performed as consolidative therapy considering PCNSL course prior to autoHSCT. In Patient 4, alloHSCT was part of an auto-/allo-transplant strategy. Disease status before alloHSCT was unconfirmed complete response (CRu) in all patients (Table 2).

In preparation for alloHSCT, all patients in this study were treated with the same busulfan-based conditioning regimen (FBC) as previously published: fludarabine (125 $\mathrm{mg} / \mathrm{m}^{2}$ i.v.), busulfan (9.6 mg/kg i.v.), cyclophosphamide $\left(120 \mathrm{mg} / \mathrm{kg}\right.$ i.v.). ${ }^{7}$ Patients were grafted with peripheral blood stem cells. GvHD prophylaxis consisted of antithymocyte globulin (ATG) or thymoglobuline, tacrolimus $(10 \mu \mathrm{g} / \mathrm{L})$, and mycophenolate mofetil (2 g/d until day $+28)$. Complete donor chimerisms were achieved in all patients at day +30 after alloHSCT (Table 2).

In general, treatment was adequately tolerated without severe complications early after FBC chemotherapy and alloHSCT. At day +107, Patient 1 (Table 2) developed severe GvHD (grade 4) of the skin and gastrointestinal (GI) tract. Despite intensive treatment with prednisolone, ATG, alemtuzumab, and etanercept, GvHD was refractory and death was due to sepsis and multiorgan failure at day +156 . Patient 3 died at day +334 due to recurrent PCNSL. Overall, 4 of 6 patients $(66.7 \%)$ are alive without further evidence of PCNSL at a minimum 3.75 years after alloHSCT.

In the long term, Patient 2 developed symptomatic cardiac dysfunction (NYHA 3) requiring special cardiologic care. This patient also suffered from femoral head necrosis treated by hip endo-prothesis. Both cardiac dysfunction and femoral head necrosis were regarded as long- term complications after chemotherapy. In the other surviving patients, no significant comorbidities nor neurologic complications were observed during follow up.

In summary, we describe the disease courses and clinical outcomes of PCNSL in six patients who were treated with alloHSCT. Despite intensive initial therapies including autoHSCT, 4 of 6 patients relapsed within 12 months, indicating a dismal prognosis. ${ }^{8}$ Intriguingly, 5 of 6 PCNSL patients remained free of lymphoma subsequent to busulfan-based chemotherapy and HLA-matched alloHSCT. Until today, only one case of successful alloHSCT in PCSNL has been reported by Varadi. ${ }^{4}$ The second patient described in the literature died from relapsing PCNSL in spite of having undergone alloHSCT. ${ }^{9}$

The optimal treatment for relapsed or refractory PCNSL is poorly defined because there are only a few prospective trials in this setting. In particular, in the case of disease relapse following autoHSCT, treatment in curative intent appears illusory. Hence, most patients receive palliative care. For example, WBRT, temsirolimus, ibrutinib, lenalidomide, and temozolomide are active and may prolong life in refractory or recurrent $(r / r)$ PCNSL; however, these therapies rarely result in long-term remissions. ${ }^{1}$

For suitable patients with $\mathrm{r} / \mathrm{r}$ aggressive lymphoma, such as diffuse large B-cell lymphoma, alloHSCT is an attractive treatment option since malignant cells are eradicated by escalating doses of cytotoxic drugs and also by immunological mechanisms. In our study, all PCNSL patients were treated with fludarabine, busulfan, and cyclophosphamide prior to alloHSCT. This conditioning

Table 2. Details of allogeneic hematopoietic stem cell transplantation (alloHSCT) in primary central nervous system lymphoma (PCNSL) patients.

\begin{tabular}{|c|c|c|c|c|c|c|c|c|c|c|}
\hline $\begin{array}{l}\text { Patient } \\
\text { n. }\end{array}$ & $\begin{array}{l}\text { Donor } \\
\text { type }\end{array}$ & HLA-Match & $\begin{array}{c}\text { Disease } \\
\text { status } \\
\text { at alloHSCT }\end{array}$ & $\begin{array}{c}\text { Chimerism } \\
(\mathrm{d}+30 / \mathrm{d}+100)\end{array}$ & $\begin{array}{l}\text { CMV serology D/R } \\
\text { CMV reactivation }\end{array}$ & $\begin{array}{l}\text { GvHD* } \\
\text { (onset) }\end{array}$ & $\begin{array}{c}\text { GvHD } \\
\text { localization }\end{array}$ & $\begin{array}{l}\text { Relapse } \\
\text { after } \\
\text { alloHSCT }\end{array}$ & $\begin{array}{c}\text { Outcome } \\
\text { last follow-up }\end{array}$ & $\begin{array}{l}\text { Complications } \\
\text { (Grade 3/4) }\end{array}$ \\
\hline 1 & MUD & $10 / 10$ & $\mathrm{CRu}$ & $100 / 100$ & $\begin{array}{c}\text { pos / pos } \\
d+21\end{array}$ & $\begin{array}{l}\text { Grade } 4 \\
(d+107)\end{array}$ & $\begin{array}{l}\text { skin, GI, } \\
\text { liver }\end{array}$ & no & $\begin{array}{c}\text { died } \\
\text { day }+156 \text { due } \\
\text { to infection/ } \\
\text { GvHD }\end{array}$ & $\begin{array}{c}\text { GvHD, } \\
\text { Sepsis, } \\
\text { CNI, } \\
\text { renal } \\
\text { insufficiency }\end{array}$ \\
\hline 2 & MRD & $10 / 10$ & $\mathrm{CRu}$ & $100 / 100$ & $\begin{array}{c}\text { neg / neg } \\
\text { no CMV infection }\end{array}$ & $\begin{array}{l}\text { Grade } 1 \\
(\mathrm{~d}+20)\end{array}$ & skin & no & $\begin{array}{c}\text { alive } \\
\text { day }+1520\end{array}$ & $\begin{array}{c}\text { CTRCD, } \\
\text { total hip } \\
\text { replacement } \\
\text { due to femoral } \\
\text { head necrosis }\end{array}$ \\
\hline 3 & MUD & $9 / 10$ & $\mathrm{CRu}$ & $100 / 100$ & $\begin{array}{c}\text { pos / neg } \\
\text { no CMV reactivation }\end{array}$ & none & & yes & $\begin{array}{c}\text { died } \\
\text { day }+334 \\
\text { due to PD }\end{array}$ & none \\
\hline 4 & MRD & $10 / 10$ & $\mathrm{CRu}$ & $100 / 100$ & $\begin{array}{c}\text { pos / pos } \\
\text { no CMV reactivation }\end{array}$ & $\begin{array}{l}\text { Grade } 1 \\
(d+27)\end{array}$ & skin & no & $\begin{array}{c}\text { alive } \\
\text { day }+1890\end{array}$ & $\begin{array}{c}\text { renal } \\
\text { insufficiency } \\
\text { (Grade I-II) }\end{array}$ \\
\hline 5 & MUD & $10 / 10$ & $\mathrm{CRu}$ & $99 / 100$ & $\begin{array}{c}\text { pos / pos } \\
\text { no CMV reactivation }\end{array}$ & & none & no & $\begin{array}{c}\text { alive } \\
\text { day }+1371\end{array}$ & none \\
\hline 6 & MRD & $10 / 10$ & $\mathrm{CRu}$ & $100 / 100$ & $\begin{array}{c}\text { pos / pos } \\
d+17\end{array}$ & & none & no & $\begin{array}{c}\text { alive } \\
\text { day }+1723\end{array}$ & none \\
\hline
\end{tabular}

MUD/MRD: matched unrelated/related donor; CMV: cytomegalovirus; GvHD: graft-versus-host-disease; GI: gastrointestinal; CNI: calcineurin-inhibitor induced nephropathy; CTRCD: cancer treatment-associated cardiac dysfunction; neg: negative; Cru: unconfirmed complete response; PD: progressive disease. * ${ }^{*}$ Glucksberg grading. 
Table 3. Compilation of studies with busulfan-based high-dose chemotherapy followed by autologous hematopoietic stem cell transplantation (autoHSCT) in primary central nervous system lymphoma (PCNSL).

\begin{tabular}{|c|c|c|c|c|c|}
\hline Study & Study type & Agents & n. of patients & Line of therapy & Overall survival \\
\hline Hyung et al..$^{16}$ & $\begin{array}{l}\text { single center, } \\
\text { retrospective }\end{array}$ & TBC vs. BuCyE & $28 / 25$ & $\begin{array}{c}\text { first line } \\
\text { consolidation }\end{array}$ & $\begin{array}{c}\text { Median OS: } \\
\text { TBC: not reached } \\
\text { BuCyE: } 4.9 \text { years }\end{array}$ \\
\hline Omuro et al..$^{17}$ & $\begin{array}{c}\text { single center, } \\
\text { phase II }\end{array}$ & TBC & 26 & $\begin{array}{c}\text { first line } \\
\text { consolidation }\end{array}$ & $\begin{array}{l}\text { Median OS: } \\
\text { not reached }\end{array}$ \\
\hline Houillier et al. ${ }^{18}$ & $\begin{array}{c}\text { multi-center } \\
\text { phase II }\end{array}$ & TBC & 66 & $\begin{array}{c}\text { first line } \\
\text { consolidation }\end{array}$ & 4-year OS: 66\% \\
\hline Soussain et $a l^{19}$ & $\begin{array}{c}\text { multi-center, } \\
\text { phase II, } \\
\text { prospective }\end{array}$ & TBC & 43 & $\begin{array}{c}\mathrm{r} / \mathrm{r} \text { PCNSL } \\
\text { or } \\
\mathrm{r} / \mathrm{r} \mathrm{IOL}\end{array}$ & $\begin{array}{l}\text { Median OS: } \\
58.6 \text { months }\end{array}$ \\
\hline DeFilipp et $a l^{20}$ & $\begin{array}{l}\text { multi-center, } \\
\text { retrospective }\end{array}$ & TBC & 46 & $\begin{array}{c}\text { first line } \\
\text { consolidation }\end{array}$ & 2-year OS: 95\% \\
\hline Choi et al. ${ }^{21}$ & $\begin{array}{l}\text { single center, } \\
\text { retrospective }\end{array}$ & Busulfan, Thiotepa & 18 & $\mathrm{r} / \mathrm{r}$ PCNSL & 5-year OS: 40\% \\
\hline Yoon et al." & $\begin{array}{l}\text { single center, } \\
\text { retrospective }\end{array}$ & BuCyE & 11 & $\begin{array}{c}\text { first line } \\
\text { consolidation }\end{array}$ & 2-year OS: 89\% \\
\hline
\end{tabular}

TBC: thiotepa, busulfan and cyclophosphamide; BuCyE: busulfan, cyclophosphamide and etoposide; OS: overall survival; r/r: refractory or recurrent; IOL: intraocular lymphoma.

regimen was developed by Glass et al. with the aims of both generating strong anti-lymphoma toxicity by chemotherapy and enabling donor $\mathrm{T}$ lymphocytes to quickly exert a significant GvL effect.

Interestingly, approximately $20 \%$ of the systemically administered busulfan dose crosses the blood-brain barrier (BBB), and, this high cerebral extraction has therapeutic implications regarding its ability to eradicate lymphoma cells. ${ }^{10}$ Furthermore, cyclophosphamide has the potential to cross the BBB. Consistent with this, significant therapeutic activity of busulfan and cyclophosphamide in PCNSL has been confirmed in different clinical protocols. However, these trials comprised thiotepa instead of fludarabine (Table 3), which was not considered to be adequate in our cohort because it had already been applied in autoHSCT prior to alloHSCT. Other regimens, such as busulfan, cyclophosphamide, and etoposide (BuCyE) showed disappointing results with a relapse rate of $55 \%$ within one year. ${ }^{11}$

Fludarabine is a pyrimidine analog which is enriched in lymphocytes because of high cellular expression of deoxy-cytidine kinase (dCK). The anti-lymphoma cytotoxic activity of fludarabine has been studied extensively. ${ }^{6}$ Recently, fludarabine could be detected in CNS lymphomas in 18F-fludarabine based positron emission tomography. Obviously, fludarabine has the the potential to cross the $\mathrm{BBB}$ and to target CNS lymphomas. ${ }^{12}$ Though not studied in detail, enhancement of cytotoxicity by fludarabine in combination with busulfan and cyclophosphamide in the FBC conditioning regimen in PCNSL is likely.

In addition to the above mentioned evidence of immunological mechanisms against PCNSL, chimeric antigen receptor-modified T-cell therapies directed against CD19-positive lymphoma and leukemia have recently been shown to have efficacy also in patients with proven CNS manifestation. ${ }^{13}$ Together with the finding of donor-derived lymphocytes in patients' CSF after alloHSCT, ${ }^{14,15}$ this indicates that immune effector cells can cross the BBB and develop anti-tumor effects in the CNS.

In summary, we reason that the therapeutic efficacy observed in PCNSL patients after alloHSCT is a result of both pharmacological and immunological mechanisms directed against PCNSL. In our patients, PCNSL status at alloHSCT was CRu; direct assessment of lymphoma responses during immune reconstitution after cessation of GvHD prophylactic immunosuppression was, therefore, unfeasible. Due to enhanced cytotoxicity of the FBC conditioning regime, the role of $\mathrm{GvL}$ remains unproven, though we believe it is probably underestimated. A controlled trial comparing busulfan-based conditioning with alloHSCT versus autoHSCT would help to unravel the relative contribution of each approach. However, feasibility of this trial will be challenging due to overall low numbers of PCNSL patients and safety considerations. Nonetheless, we believe, that the promising results in our cohort support additional efforts to exploit the therapeutic potential of alloHSCT in the challenging situation of PCNSL following autoHSCT.

Thomas Mika, ${ }^{1 *}$ Swetlana Ladigan, ${ }^{1 *}$ Alexander Baraniskin, Deepak Vangala, Sabine Seidel, ${ }^{2}$ Olaf Hopfer, ${ }^{3}$ Michael Kieh ${ }^{3}$ and Roland Schroers

*TM and SL contributed equally.

${ }^{1}$ Department of Hematology and Oncology, Universitätsklinikum Knappschaftskrankenhaus Bochum; 'Department of Neurology, Universitätsklinikum Knappschaftskrankenhaus Bochum and ${ }^{3}$ Department of Medicine I, Klinikum Frankfurt, Frankfurt (Oder), Germany

Correspondence: ROLAND SCHROERS/MICHAEL KIEHL Roland.Schroers@rub.de/Michael.Kiehl@klinikumffo.de doi:10.3324/haematol.2019.227199

Information on authorship, contributions, and financial \& other disclosures was provided by the authors and is available with the online version of this article at www. haematologica.org. 


\section{References}

1. Mendez JS, Grommes C. Treatment of Primary Central Nervous System Lymphoma: From Chemotherapy to Small Molecules. Am Soc Clin Oncol Educ Book. 2018(38):604-15.

2. Illerhaus G, Schorb E, Kasenda B. Novel agents for primary central nervous system lymphoma: evidence and perspectives. Blood. 2018; 132(7):681-688.

3. Nayak L, Iwamoto FM, LaCasce A, et al. PD-1 blockade with nivolumab in relapsed/refractory primary central nervous system and testicular lymphoma. Blood. 2017;129(23):3071-3073.

4. Varadi G, Or R, Kapelushnik J, et al. Graft-versus-lymphoma effect after allogeneic peripheral blood stem cell transplantation for primary central nervous system lymphoma. Leuk Lymphoma. 1999; 34(1-2):185-190

5. Kasenda B, Ihorst G, Schroers R, et al. High-dose chemotherapy with autologous haematopoietic stem cell support for relapsed or refractory primary CNS lymphoma: a prospective multicentre trial by the German Cooperative PCNSL study group. Leukemia. 2017; 31(12):2623-2629.

6. Illerhaus G, Kasenda B, Ihorst G, et al. High-dose chemotherapy with autologous haemopoietic stem cell transplantation for newly diagnosed primary CNS lymphoma: a prospective, single-arm, phase 2 trial. Lancet Haematol. 2016;3(8):e388-397.

7. Glass B, Hasenkamp J, Wulf G, et al. Rituximab after lymphomadirected conditioning and allogeneic stem-cell transplantation for relapsed and refractory aggressive non-Hodgkin lymphoma (DSHNHL R3): an open-label, randomised, phase 2 trial. Lancet Oncol. 2014;15(7):757-766.

8. Langner-Lemercier S, Houillier C, Soussain C, et al. Primary CNS lymphoma at first relapse/progression: characteristics, management, and outcome of 256 patients from the French LOC network. Neuro Oncol. 2016;18(9):1297-1303.

9. Atilla E, Sahin U, Atilla PA, et al. Allogeneic stem cell transplantation for relapsed primary central nervous system lymphoma: Is it feasible? Hematol Oncol Stem Cell Ther. 2019;12(4):220-225

10. Hassan M, Ehrsson H, Ljungman P. Aspects concerning busulfan pharmacokinetics and bioavailability. Leuk Lymphoma. 1996;22(56):395-407.

11. Yoon DH, Lee DH, Choi DR, et al. Feasibility of BU, CY and etoposide (BUCYE), and auto-SCT in patients with newly diagnosed primary CNS lymphoma: a single-center experience. Bone Marrow Transplant. 2011;46(1):105-109.

12. Hovhannisyan N, Fillesoye F, Guillouet S, et al. 18FFludarabine-PET as a promising tool for differentiating CNS lymphoma and glioblastoma: Comparative analysis with 18FFDG in human xenograft models. Theranostics. 2018;8(16):4563-4573.

13. Maude SL, Frey N, Shaw PA, et al. Chimeric antigen receptor T cells for sustained remissions in leukemia. N Engl J Med. 2014; 371(16):1507-1517.

14. Waterhouse M, Bartsch I, Bertz H, Duyster J, Finke J. Cerebrospinal fluid chimerism analysis in patients with neurological symptoms after allogeneic cell transplantation. Bone Marrow Transplant. 2016; 51(1):127-131.

15. Spruit JL, Fagoaga OR, Savaşan S. Donor cell chimerism evaluation in cerebrospinal fluid by short tandem repeat analysis following allogeneic hematopoietic stem cell transplantation. Hum Immunol. 2018;79(7):537-538.

16. Hyung J, Hong JY, Yoon DH, et al. Thiotepa, busulfan, and cyclophosphamide or busulfan, cyclophosphamide, and etoposide high-dose chemotherapy followed by autologous stem cell transplantation for consolidation of primary central nervous system lymphoma. Ann Hematol. 2019;98(7):1657-1664.

17. Omuro A, Correa DD, DeAngelis LM, et al. R-MPV followed by high-dose chemotherapy with TBC and autologous stem-cell transplant for newly diagnosed primary CNS lymphoma. Blood. 2015; 125(9):1403-1410.

18. Houillier C, Taillandier L, Dureau S, et al. Radiotherapy or Autologous Stem-Cell Transplantation for Primary CNS Lymphoma in Patients 60 Years of Age and Younger: Results of the Intergroup ANOCEF-GOELAMS Randomized Phase II PRECIS Study. J Clin Oncol. 2019;37(10):823-833.

19. Soussain C, Hoang-Xuan K, Taillandier L, et al. Intensive chemotherapy followed by hematopoietic stem-cell rescue for refractory and recurrent primary CNS and intraocular lymphoma: Société Française de Greffe de Moëlle Osseuse-Thérapie Cellulaire. J Clin Oncol. 2008; 26(15):2512-2518.

20. DeFilipp Z, Li S, El-Jawahri A, et al. High-dose chemotherapy with thiotepa, busulfan, and cyclophosphamide and autologous stem cell transplantation for patients with primary central nervous system lymphoma in first complete remission. Cancer. 2017;123(16):30733079.

21. Choi MK, Kang ES, Kim DW, et al. Treatment outcome of relapsed/refractory primary central nervous system diffuse large Bcell lymphoma: a single-center experience of autologous stem cell transplantation. Int J Hematol. 2013;98(3):346-354. 